\title{
POVERTY, INCOME DISTRIBUTION AND SOCIAL WELFARE IN DEVELOPMENT PROCESS
}

\author{
Osman Cenk KANCA ${ }^{1}$
}

\author{
Yusuf AKAN ${ }^{2}$
}

\begin{abstract}
Among the most considered topics on Turkish economy are poverty, income distribution and social benefits. It gains importance to determine the relations among the above mentioned development indicators and it is thought that this interaction should be taken into account in the fiscal and economic policies to be formed in Turkey being among the developing countries. The aim of this study is to evaluate the relationship among the rate of poverty, Gini coefficient and social benefits by using time series econometric techniques in the period of 1990-2016. The findings obtained as a result of the analysis show that the social benefits in Turkey affect the Gini coefficient in a lessening way in other words has a lessening effect on the income injustices. In addition, a statistically significant causality relation between Gini coefficient and poverty also exists.
\end{abstract}

Keywords: Development, Poverty, Income Distribution, Social Benefits.

JEL Code: O30, I30, D33, H50.

\section{Introduction}

The developmental phenomenon, which concerns the entire society, is an important part of the economic theory which influences the structure of the national economies and thus the welfare of the people. Poverty, income distribution, and social welfare benefits were started to be perceived as political, social, and economic issues with the period of change in the world that initiated especially after 1980.

To eliminate the problem of poverty and the problem of income distribution and to provide a more prosperous life have always come to the fore in terms of public policies. Therefore, social welfare has been a very important policy tool in the hands of political powers and used by them frequently in all countries of the world. When the issue is discussed with regard to Turkey and when a series of financial-political-economic spiral experiences in the post-1980 period are considered, the determination of the relation between "three" arguments which are significant indicators of development is of vital importance.

In general, factors such as lack of resources, weakness in economic structures of countries and defects in their financial situations, terrorism and wars, unemployment, natural disasters, change in population structure, immigration, and economic-political crises can be considered among the causes of poverty. In this regard, "poverty index" is used as an important indicator in poverty measurement (Maxwell, 1999). Income distribution is the proportionate share of total

\footnotetext{
1 Asst. Prof. Dr., Ataturk University, Erzurum Vocational School of Higher Education, Department of Foreign Trade, osmancenkkanca@hotmail.com

2 Prof., PhD, Ataturk University, Faculty of Economics and Administrative Sciences, Department of Economics, yusufakan@yahoo.com
} 
income in an economy among economic actors. In other words, it is the amount of the share social groups receive from the national income. The degree of fairness of income distribution in an economy is determined with the help of "Gini Coefficient" (Ulusoy, 2006: 10). On the other hand, social welfare, which is one of the tools of the public sector to intervene in the economy and which is a prerequisite for being a social state, involves in-kind and financial aids which makes it possible for national income to be transferred from one social group toanother without anything in return. This can be considered as a transfer of income by formal-semi-formal and voluntary organizations to persons who have been devoid of self-support.

Towards the end of 1970s Turkey came to a deadlock in terms of economic, social, political and financial issues, which made it compulsory to make structural transformations in the economy. As a result, fundamental structural changes in economic policies were implemented in Turkey's economy in 1980. However, the instabilities and deteriorating economic balances towards the end of the 1980s continued by gaining momentum in the 1990s, and this created a number of macroeconomic problems such as poverty and imbalance in income distribution. The occurrence of this situation led to more frequent use of social welfare, which is one of the tools of fiscal policy.

In the study, the possible relationship between poverty, income distribution and social welfare in Turkey was explored. The first chapter involves discussion on the general state of the case in Turkey, which is followed by second chapter which provides samples from the country. In the third chapter, econometric methods were explained with the data set used in the study. In the fourth chapter, empirical findings obtained from the methodology were presented. In the conclusion chapter, policy recommendations were made in the light of the empirical findings.

\section{Literature}

In the literature, various related studies have been carried out on developed and developing countries. Kenworthy (1999) discussed fifteen industrialized countries for the period 1960-1991 as a comparison with the OLS method and reached empirical findings that social welfare spending reduced poverty. Atkinson (2000) found that the increase in transfer expenditures / GDP ratio in the context of social expenditures led to a decrease in the poverty rate of the French and British economies. Förster and D'Ercole (2005) examined the 27 OECD (Organisation for Economic Co-operation and Development) countries in their study for the second half of the 1990s and reached empirical evidence that the improvement in income distribution reduced poverty

As for Turkey's economy, Sarisoy and Koç (2010) studied the period 2002-2007 and found in the social regression testing done that social public expenditures reduce poverty rate. Tüğen and Eroğlu (2017) studied the relationship between poverty and social spending in Turkey and indicated that social spending is extremely important for poverty reduction.

\section{Data Set,Econometric Method and Findings}

The data set used in this study covers the period of 1990-2016, and the social welfare/ GNP (SA) and poverty rate (POV) (Human Development Index [HDI] representing poverty was used as a proxy variable), BUMKO (General Directorate of Budget and Fiscal Control in Turkey) were gathered from the reports of UNDP's (United Nations DevelopmentProgram) and TUIK (Turkish Statistical Institute) data distribution system; The Gini coefficient (GINI) series was compiled from the official website of TUIK. 
The border test technique developed by Pesaran et al. (2001) is a more effective method compared to other traditional cointegration (Engle-Granger and Johansen cointegration). Moreover, this approach allows for very strong empirical results at the point of examining the long and short term relationship. In the boundary test method, it is possible to test the cointegration relationship between variables, irrespective of whether the variables are I (0), I (1) or mutually co-integrated. Boundary test consists of two stages, firstly whether there is a cointegration relationship between variables is checked. Later, short and long term relationships are estimated by using ARDL (Autoregressive Distributed Lag) model if there is a cointegration relationship between variables (Tanrı̈ver and Yamak, 2015: 192).

According to ADF unit root test results; the poverty rate (POV) and Gini coefficient (GINI) were stable at the variable level, while the social welfare / GDP (SA) variable was found to be stationary at first difference. Then, it was seen that the boundary test result calculated at $1 \%$ significance level exceeded the upper limit critical value and a long term relationship was found between the variables. In the short term coefficients, the current value of the social assistance and the third delay coefficients were statistically significant at the $10 \%$ significance level. According to the approximate results; it was observed that social welfare had a negative effect on GINI coefficient and there was no statistically significant effect in poverty rate. Finally, the TodaYamamoto test yielded a causality relationship from the GINI variable to the POV variable at a significance level of $1 \%$.

\section{Conclusion}

Poverty and income distribution, which often occupy agenda in Turkey, like in many other developing countries, are economic issues. In this regard, social welfare, which is one of the policy tools of the state, can assume important tasks in solving these problems. In this context, the study focuses on poverty, income distribution, social welfare and their relationship with each other in Turkey in the period after 1990. For this purpose, a model was formed and econometric estimation was made by limit test.

This study aimed to determine the level of mutual interaction among "poverty", "income distribution" and "social welfare" in the period between 1990 and 2016 in Turkey. ARDL boundary test methodology was used in the study. In the period mentioned, some evidence which indicates that social welfare reduces "Gini coefficient", which optimizes income distribution in Turkey's economy. However, there were no statistically significant findings that the poverty rate decreased the Gini coefficient. On the other hand, the Toda-Yamamoto test results indicated a causality from the Gini coefficient (GINI) to the poverty rate (POV). When these findings are evaluated with regard to Turkey's economy, an optimization in income distribution may be considered to reduce poverty. 


\section{References}

Atkinson, A. (2000). "A European Social Agenda: Poverty Benchmarking and Social Transfers", Euromod Working Paper Series, 3, 00, Jully.

Caminada, K., Goudswaard, K. \& Koster, F. (2012). "Social Income Transfers and Poverty: A CrossCountry Analysis for OECD Countries", International Journal of Social Welfare, 21, 115-126.

Förster, M. \& D'Ercole, M. M. (2005). Income Distribution and Poverty in OECD Countries in the Second Half of the 1990s, OECD Social, Employment and Migration Working Papers, pp. 1-79.

Günaydın, İ. \& Yıldız, B. (2016). “Vergi Politikası ile Yoksulluk Azaltılabilir mi?”, Küresel iktisat ve İsletme Çalışmaları Dergisi, 5 (9), 90-104.

Kenworthy, L. (1999). "Do Social-Welfare Policies Reduce Poverty? A Cross-National Assessment", The University of North Carolina Press, Social Forces, 77(3), pp. 1119-1139.

Maxwell, S. (1999). "The Meaning and Measurement of Poverty", Overseas Development Institute, 3, pp. 1-4.

Pesaran, H., Shin, Y. \& Smith, R. J. (2001). "Bound Testing Approaches to the Analysis of Long Run Relationships", Journal of Applied Econometrics, 16 (3), pp. 289-326.

Sarısoy, i., \& Koç, S., (2010). "Türkiye'de Kamu Sosyal Transfer Harcamalarının Yoksulluğu Azaltmadaki Etkilerinin Ekonometrik Analizi", Maliye Dergisi, 158, ss. 326-348.

Tanrı̈̈ver, B. \& Yamak, N. (2015). “Nominal Faiz Oranı-Genel Fiyat Düzeyi Illişkisinin Gibson Paradoksu Çerçevesinde Analizi”, Maliye Dergisi, 168, ss. 186-200.

Tokatlıoğlu, M. \& Selen, U. (2017). Maliye Politikası, Bursa, Ekin Yayınevi.

Tüğen, K. \& Eroğlu, A. (2017). "Yoksulluğu Önlemeye Yönelik Sosyal Bütçe Uygulamaları ve Türkiye Açısından Değerlendirilmesi", Finans Politik \& Ekonomik Yorumlar, 54 (627), ss. 31-46.

Ulusoy, A. (2006). Maliye Politikası, Trabzon, Üçyol Kitabevi.

www.kalkinma.gov.tr 